\title{
A Development of Homolog Sequence of Eimeria tenella Partial Genome as a Probe for Molecular Diagnosis of Coccidiosis
}

\author{
Sumartono \\ Parasitology Department, Faculty of Veterinary Medicine Gadjah Mada University, Jl. Olah Raga \\ Karangmalang Yogyakarta 55281, Indonesia.
}

\begin{abstract}
The goal of the research was to develop a homolog sequence of Eimeria tenella partial genome as a molecular probe for diagnose coccidiosis using dot blot method. A probe of homolog sequence of E.tenella partial genome and a non radioactive label, dig-11-dUTP, were used for this research. Four concentrations of molecular probe labeled with dig-11-dUTP, namely, $158,33 \mathrm{pg} / \mu \mathrm{l}, 52,25 \mathrm{pg} / \mu \mathrm{l}, 15,83 \mathrm{pg} / \mu \mathrm{l}$ and $5,225 \mathrm{pg} / \mu \mathrm{l}$ were tested to detect $0,6551 \mu \mathrm{g}$ DNA target. The procedure of labeling and hybridization detection between DNA target with the molecular probe labeled with dig-11-dUTP were carried out with Digh high prime DNA labeling and detection starter Kit I. The conclusion of the research was that $52,25 \mathrm{pg} / \mu 1$ molecular probe or more which its sequence GGCA CAGTATCCTCCTTCAGGGCAGGG CTCGCACTGGTCAAA CGCGG TAC CATT could detect DNA target by dot blot method.
\end{abstract}

Keywords: coccidiosis, E. tenella genome, molecular probe, dot blot hybridization

\section{Introduction}

One of the harmful of chicken diseases is coccidiosis. According to Groves (1986), there are nine species of Eimeria as causative agents of chickens coccidiosis. The most pathogene of Eimeria species is $E$. tenella (Reid et al., 1984; Kaufmann, 1996, Robert and Janovy, 2000). The life cycle of the Eimeria consist of three phases, namely, sporogony, schizogony and gametogony (Soulsby, 1982; Kaufmann, 1996). According to Calnek (1991) and Soulsby (1982), The schizogony II phase is the most destructive for the chicken. The diseases may be diagnosed based on the clinical symptoms, oocysts finding in the faeces and on the postmortem examination, it may be diagnosed based on Eimeria stadia finding in the chicken intestine (Soulsby, 1982;

Corresponding author: Sumartono, Department of Parasitology, Faculty of Veterinary Medicine, Gadjah Mada University, Jl. Olah Raga Karangmalang, Yogyakarta 55281, Indonesia. Tel: 62-274-649-62203; Email: marton@ugm.ac.id
Morgan and Hawkins, 1995; Bowman, 2003). Recently, many molecular methods have been developed to diagnose coccidiosis such as: DNA (deoxyribonucleic acid) detection and identification (MacPherson and Gajadhar, 1993; Barker, 1990; Reischsl et al., 2003). According to Shirley (2000), the genom of $E$. tenella is $60 \mathrm{Mbp}$ in the ca. 14 chromosom, whereas according to Anonim (2001) the genom size is $70 \mathrm{Mbp}$. In Indonesia, the molecular diagnose for coccidiosis have not developed yet. Sumartono et al. (2004) sequenced a homolog band of partial genom from five Indonesian isolates.

The aim of the research is to study the sequenced band as a probe to molecular diagnose of coccidiosis using dot blot hybridization (Salehzada dan Taha , 1992).

\section{Materials and Methods}

The main materials was $3,54.10^{6}$ oocystes isolat Yogya, an oligonukleotida : GGCACAGTATCCTCCTTCAGGGCAGGGCT CGCACTGGTCAAACGCGGTAC CATT ( Sumartono et al., 2004), and Dig. Control test 
strip, Dig high prime DNA labeling and detection starter Kit I (Roche, Germany).

\section{Isolation of E. tenella genom}

The genom was isolated from 3,54.106 E. tenella oocystes of Yogya isolate. The isolation was carried out using the modification of MacPerson and Gajadhar methode (Sumartono et al., 2004).

\section{Preparation of homolog sequence as a probe candidate}

The probe candidate used in the research was from Sumartono et al., (2004). Sequence analyses was done either manually or using gene analyzer. The probe candidate was chosen by comparing sequence manually analysed to sequence using gene analyzer.

\section{Probe labeling}

Probe labeling was done with a non radioaktif reporter, digoxigenin-11-dUTP. A number of $2 \mu \mathrm{l}$ probe candidate $(1 \mathrm{~g})$ and 14 $\mathrm{ml}$ aquadest were filled in a $1.5 \mathrm{ml}$ eppendorf tube. After boiling for 10 minute, the tube was subsequently chilled on ice. Then, a number of $4 \mu \mathrm{l}$ dig high prime (consist of Klenow enzyme, labeling grade, dig-11dUTP, alkaly labil, dATP, dCTP, dGTP, dTTP and reaction buffer optimized with $50 \%$ gliserol) was added. Before incubation at $37^{\circ} \mathrm{C}$ for overnight, the solution was condensed for a moment by centrifugation. For stopping the reaction, a number of $2 \mu \mathrm{l}$ 0,2 M EDTA ( $\mathrm{pH} 8$ ) was added to the tube.

\section{Quantification of labeled probe}

Quantification of labeled probe bounded by antibody anti dig-11-dUTP was estimated using dig DNA labeling and detection Kit and DIG quantification teststrips (Boehringer, Germany). Principally, the quantification was done by comparing hybridization of labeled probe test to a controle teststrip contained a known concentration. Solution preparation, dilution of labeled probe, teststrip preparation and detection of labeled probe were carried out according to the procedure of the Kits.

\section{Conception of diagnose model for an} application of dot blot hybridization

A teststrip model was designed for an application of dot blot hybridization. The teststrip consisted of 5 compartment (compartment 1: Blank, compartment 2: A, compartment 3: B, compartment 4: $\mathrm{C}$, and Compartment 5: D)

\section{Optimalisation of labeled probe use}

The procedure consisted of teststrip preparation, series dilution of labeled probe in hybridization solution, hybridization and immunology detection.

For teststrip preparation, a number of 8 teststrips was divided into 4 groups (I-IV), each group consisted of 2 teststrips. A number of $10 \mu \mathrm{l}$ E. tenella DNA of Yogya isolat $(1 \mu \mathrm{l}=0.6551 \mu \mathrm{g}$ DNA $)$ was boiled at $100^{\circ} \mathrm{C}$ for $10 \mathrm{~min}$ and, then, it was chilled on ice. On compartment B of teststrips, a number of $1 \mu \mathrm{l}$ E. tenella DNA was dotted and $1 \mu \mathrm{lddH_{2 }} 0$ was dotted on compartment C. After washing in 2x SSC for a moment, those teststripts were baked at $80^{\circ} \mathrm{C}$ for $2 \mathrm{~h}$. Teststripts can be stored in refrigerator (2 $\left.8^{\circ} \mathrm{C}\right)$.

Preparation of series dilution of labeled probe in hybridization solution was carried out in three steps. The first step was preparation of hybridization of solution, the second step was preparation of a series dilution of labeled probe and the third step was preparation of a series dilution of labeled probe in hybridization solution.

Hybridization solution was made by diluting Dig. Easy Hyb. granule in $64 \mathrm{ml}$ $\mathrm{ddH}_{2} \mathrm{O}$ and it was stirred for $5 \mathrm{~min}$ at $37^{\circ} \mathrm{C}$. For making a series dilution of labeled probe in DNA dilution buffer, it was done by the same procedure with the procedure of 
dilution of the Kit. Series dilution of labeled probe in hybridation solution were made by mixing the two solutions. Dig. Easy Hyb. solution was divided into 4 aliquot, each consisted of $1 \mathrm{ml}$. A number of $2 \mu \mathrm{l}$ of every serie dilution of labeled probe was added into the aliquot so there were 4 aliquots with different concentration of labeled probe. Those aliquots were stored at -15 to $-25^{\circ} \mathrm{C}$.

Before making hybridization between labeled probe to DNA target, the temperature of hybridization was estimated and Dig.Easy Hyb. solution was heated at hybridization temperature. The estimation was carried out according to Keller and Manak (1989). The prepared teststrips was filled in the plastic sachets, each consisted of 2 teststripts according to their code. A number of $1 \mathrm{ml}$ of heated Dig. Easy Hyb. solution was added in the sachets. Those sachets were agitated moderately for $30 \mathrm{~min}$. After pippeting out solution in the sachets, the sachet was filled in $1 \mathrm{ml}$ of serie dilution of labeled probe in Dig. Easy Hyb. solution. Those sachets was reagitated moderately for $4 \mathrm{~h}$. The solution in the sachet was repippeted out and, then, it was washed $2 x$ with the $50^{\circ} \mathrm{C}$ of washing solution. The washing was done by moderate agitation for 5 min.

Hybridization between labeled probe to DNA target was detected by using an antibody-antiDig-AP (AP: alkaline phosphatase). A series dilution of labeled DNA control were made by the same procedure with dilution procedure of labeled probe candidate. A number of $1 \mu \mathrm{l}$ control solution was dotted on compartment A of the teststrip according its concentration, and as a negative control, on compartment $C$ was dotted with $\mathrm{ddH}_{2} \mathrm{O}$. Detection procedure of the hybrid was carried out by the same procedure with procedure of the Kit.

The data was analysed descriptively.

\section{Results and Discussion}

On OD260, the genome of E. tenella obtained was 0.262 , Its means that the genome in the sample was: $0.262 \times 50 \times 50$ $($ value dilution $)=655$, or the genome concentration in the elution $(50 \mu \mathrm{l})$ was: 655 x $0.05=32.75 \mu \mathrm{g} / 50 \mu \mathrm{l}$ or $0.655 \mu \mathrm{g} / \mu \mathrm{l}$.

Probe candidate from Sumartono et al. (2004) analysed with two different method was presented on Table 1.

Tabel 1 showed that, based on the longer of the probe, the two sequence maybe to be a probe because, these sequences were not too longer to be a probe (77 nt vs $54 \mathrm{nt}$ ). According to Keller and Manak (1989), the good probe contains 50 bases, whereas, the good probe may be longer, 100-300 bases (Leitch at al., 1994). The GC ratio of two sequence $(50.6 \%$ vs $57 \%$ ) was higher than GC ratio according to Keller and Manak (1989) (40\% - 60\%). Nevertheless, the number of the same nucleotide sequence was fewer in the sequence analysed by gene analyzer than in sequence analysed manually ( 3 ( 2 (GGG ), 1 (AAA ) ) vs 5 ( 3 (GGG), 2 (AAA) ). So, the probe candidate used in the research was GGCACAGTATCCTCCTTCAGGGC AGGGCTCGCACTGGTCAAACGCGGT ACCATT.

Table 1. Probe candidate analysed manually and using gene analyzer.

\begin{tabular}{ll}
\hline \multicolumn{1}{c}{$\begin{array}{c}\text { Manual Anlyses } \\
\text { (Result. HBXIl/1) }\end{array}$} & \multicolumn{1}{c}{ GenetyxMax Analyses } \\
\hline & \\
AGGGCAGGGCTCGCACTGGTCAAAG & GGCACAGTATCCTCCTTCAGGGCAG \\
GCGGTACCATTTGGGTCCTTTCGTAT & GGCTCGCACTGGTCAAACGCGGTAC \\
GGTGCCTAAATTCATGACCACACTA TT & CATT \\
\hline
\end{tabular}


Labeling of molecular probe candidate for coccidiosis diagnose presented on the Figure 1. Concentration of probe candidate in stock was $825 \mu \mathrm{g} / 1500 \mu \mathrm{l}$ or $0.55 \mu \mathrm{g} / \mu \mathrm{l}$. The number of labeled probe candidate was $2 \mu \mathrm{l}$ or $1.1 \mu \mathrm{g}(1100 \mathrm{ng})$. By incubation for 20 $\mathrm{h}$ in $20 \mu \mathrm{l}$ solution, its means that labeled probe candidate was $38 / 100 \times 1100 \mathrm{pg}=418$ ng in $20 \mu \mathrm{l}$ solution or $20.9 \mathrm{ng} / \mu \mathrm{l}$. For making dilution of the labeled candidate probe, $1 \mu$ the labeled probe was diluted to $40 \mu \mathrm{l}$, its means that in $1 \mu \mathrm{l}$ of this solution contained $0.5225 \mathrm{ng}$ labeled probe. In the 10 $\mu 1$ dilution A contained $5.225 \mathrm{ng}$ labeled probe candidate, the solution was diluted with DNA dilution buffer into $33 \mu \mathrm{l}$. For dotting, it was used $1 \mu \mathrm{l}$ of dilution $\mathrm{A}$ or $158.33 \mathrm{pg}$, so its means that for dilution B was $52.25 \mathrm{pg}$, dilution $\mathrm{C}$ was $15.83 \mathrm{pg}$, dilution D was $5.225 \mathrm{pg}$ and dilution $\mathrm{E}$ was 1.583 pg. Figure 1 showed that on teststrip control, the antibody anti dig-11-dUTP could detect the labeled probe candidate in all compartments (3 pg to 300 pg), whereas, on probe candidate teststrip the antibody only detected the probe 5.225 to $158.33 \mathrm{pg}$. Nevertheless, Its means that the smallest probe candidate detected was $>3 \mathrm{pg}$. According to the protocol of the Kit, the labeled probe can be used for the next procedure (hybridization).

The hybridization temperature was estimated according to Keller dan Manak formula (1989).

$\mathrm{T}_{\mathrm{m}}=49.82+0.41(\% \mathrm{G}+\mathrm{C})-(600 / 1)(1$

: number of probe nucleotide)

$\mathrm{T}_{\text {opt }}: \mathrm{T}_{\mathrm{m}}-20$ to $25^{\circ} \mathrm{C}$

In the research :

$\%(G+C)$ probe candidate was 59.26, and 1 $=54, \mathrm{~T}_{\mathrm{m}}=49.82+0.41(59.26)-(600 / 54)=$ $49.82+24.30-11.11=63.01$. So, for hybridization, the optimal temperature was $38.01^{\circ} \mathrm{C}-43.01^{\circ} \mathrm{C}$ or $40.51^{\circ} \mathrm{C}$.

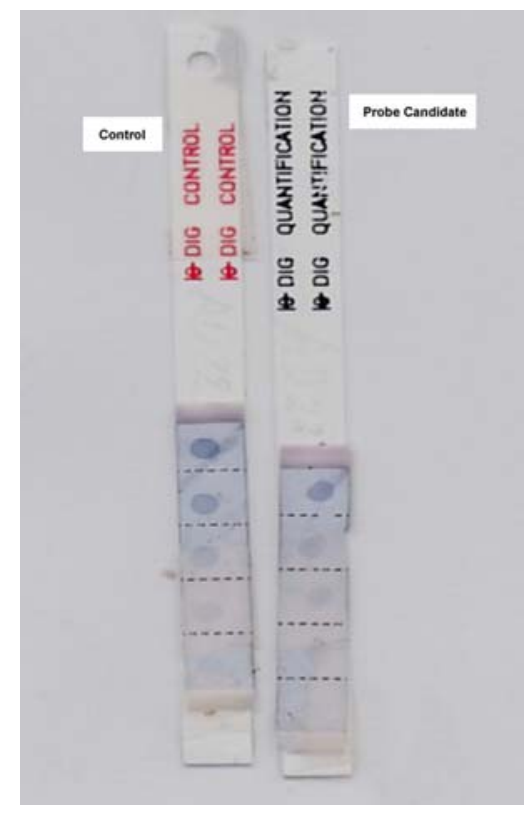

Figure 1. Labeling of molecular probe candidate with non radioaktif dig -11-dUTP.

The optimalisation of labeled probe use for coccidiosis diagnose was presented on Figure 2.

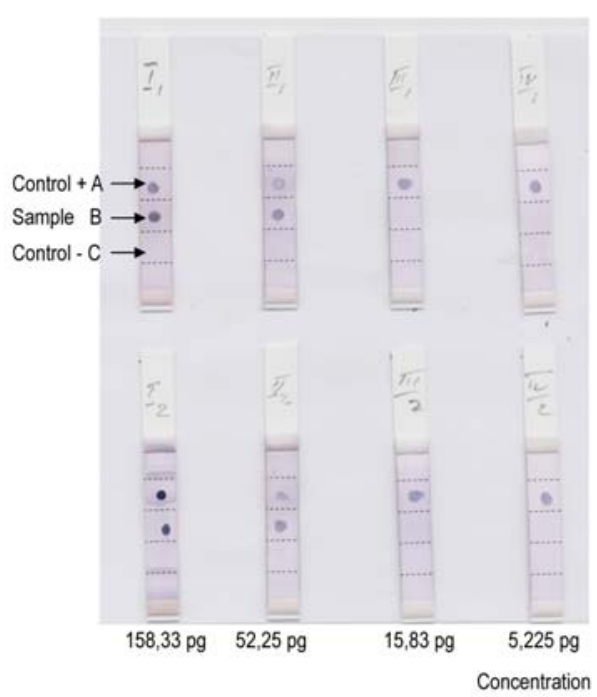

Figure 2. Result of the optimalisation of labeled probe use. 
On Figure 2 there were 2 lines teststrips, namely, line $I_{1}-I V_{1}$ and line $I_{2}-I V_{2}$. Line $I_{2}-$ $\mathrm{IV}_{2}$ was a repetion of teststrip $\mathrm{I}_{1}-\mathrm{IV}_{1}$. On the teststrip showed that the dot was coloured. The formation of the coloured dot showed that a reaction between antibody-antidig11-dUTP conjugated with an enzyme, alkaline phosphatase (AP) to the substrat NBT/ BCIP. The formation of coloured dot on compartment control positive (A) on all teststrip showed that the test was well procedure, its means that antibody-antidig11-dUTP could detect dig-11-dUTP bounded by the probe. The formation of coloured dot on compartmens (B) of teststrip $\left(\mathrm{I}_{1}, \mathrm{II}_{1}, \mathrm{I}_{2}\right.$ and $\mathrm{II}_{2}$ ) showed that the probe could detect $E$. tenella DNA fixed on the teststrip $(0.6551 \mu \mathrm{g})$. On the same compartment (B), on teststrips $\mathrm{III}_{1}, \mathrm{IV}_{1}, \mathrm{IIII}_{2}$ and $\mathrm{IV}_{2}$, the coloured dot were not appear because of lower concentration of labeled probe. The On compartment $C$ of the teststrips, the coloured dot, also, was not appears because no DNA target on the compartment (control negative), and labeled probe washed away at the time of detection procedures. That means that the probe candidate which its sequence was GGCACAGTATCCTCCTTCAGGGCAGGGCT CGCACTGGTCAAACGCGGTACCATT and on minimal concentrationl $52.25 \mathrm{pg}$ could be used to detect $0.6551 \mu \mathrm{g}$ E. tenella DNA by dot blot application.

The research concluded that a sequence, GGCACAGTATCCTCCTTCAGGGCAGGGCTC GCACTGGTCAAACGCGGTACCATT, of E. tenella partial genome could be used to a moleculer probe to coccidioses diagnose by dot blot application on minimal concentration $52.25 \mathrm{pg}$.

\section{Acknowledgment}

We would like to thank The Director General of High Education, National Education Departement of Indonesie for financial support via "Hibah Bersaing
Project" XII/1 No.: 018/P4PT/DPPM/ PHB/XII/III/ 2004.

\section{References}

Anonim, 2001. http://www.cbs.dtu.dk/ $\mathrm{d}$ a $\mathrm{t} a \mathrm{~b}$ a s e / D O G S / abbr.table.common.txt

Barker, R.H., 1990. DNA probe diagnosis of parasitic infection. Exp. Parasitol., 70, 494-499.

Bowman, D., 2003. Georgis' Parasitology for veterinarians. $8^{\text {th }}$ ed. Saunders, 91-98.

Calnek, B.W., Barnes, H.J., Beard, C.W., Reid, W.M. and Yorder, Jr.H.W., 1991. Disease of poultry. Month ed. Iowa , Ames, USA: The Iowa State University Press, 786-788.

Groves, P.J., 1986. Coccidiosis in chickens, turkey and ducks in poultry health., 36175.

Kaufmann, J., 1996. Parasitic infections of domestic animals. A diagnostic manual. Basel, Boston, Berlin: Birkhauser Verlog, 17-21 dan 341-347.

Keller, G.H and Manak, M.M., 1989. DNA probes. Macmillan Publisher Ltd, 116.

Leitch, A.R., Schwarzacher,T., Jackson, D. and Leitch, I.J., 1994. In situ hybridation : a practical guide. Bios Scientific Publisher, 33

MacPherson, J.M and Gajadhar, A.A., 1993. Differentiation of seven Eimeria species by random amplified polymorphic DNA. Veterinary Parasitology. 45, 257-266.

Morgan, B.B. and Hawkins, P.A., 1995. Veterinary Protozoology. $2^{\text {nd }}$ ed. Burgess Publishing Company Minnesota, 7679.

Reid, W.M., Long L and McDougald, L.R., 1984. Coccidiosis in disease of poultry. $8^{\text {th }}$ ed. In Hoffstad, M.S., Barner, H.J., Calnek, B.W., Reid, W.M. and Yorder, H.W., ed. Iowa, USA: The Iowa State University Press, 693-708. 
Reischsl, U., Bretagne, S., Kruger, D., Ernault, P. and Costa, J.M., 2003. Comparison of two DNA targets for the diagnosis of toxoplasmosis by real-time PCR using fluorescence resonance energy transfer hybridization probes. BMC. Infect. Dis., 3 (1), 7.

Roberts, L.S and Janovy, J., 2000. Foundation of Parasitology. MacGrawHill, 122-126.

Salehzada, T and Taha M.N., 1992. Licence de Biochemie. Biochemie des proteines. Biochemie Moleculaire. Travaux Practique de Biochemie
Universite Montpellier II. U.F.RS.F.A., 10-22.

Shirley, M.W., 2000. The genome of Eimeria spp. Special reference to Eimeria tenella, a coccidium from the chicken. Int. J. Parasit., 30, 485-493.

Soulsby, E.J.L., 1982. Helminths, Arthropods and protozoa of domesticated animal. $7^{\text {th }}$ ed. London: Bailliere Tindall, 507645.

Sumartono, Widodo, D.P. dan Nurcahyo, W., 2004. Pengembangan probe molekuler untuk optimalisasi diagnosis koksidiosis. Laporan Penelitian Th. I HB XII. 